\title{
Identifikasi Faktor Risiko Keselamatan Pada Proyek Konstruksi Bangunan Gedung di Indonesia dalam 10 Tahun Terakhir (2011-2021): Kajian Literatur
}

\author{
M Kholis Ardiansyah ${ }^{1}$, Sony Irawan ${ }^{1}$, Humiras Hardi Purba ${ }^{2}$ \\ ${ }^{I}$ Departemen Teknik Sipil, Universitas Mercu Buana, Jakarta \\ ${ }^{2}$ Departemen Teknik Industri, Universitas Mercu Buana, Jakarta
}

\section{INFORMASI ARTIKEL}

$\begin{array}{ll}\text { Diterima } & : \text { 14 November } 2021 \\ \text { Direvisi } & : 24 \text { Februari } 2022 \\ \text { Diterbitkan } & : 26 \text { Februari } 2022\end{array}$

\section{KATA KUNCI}

Proyek Konstruksi Gedung, Risiko K3, Zero Accident

\begin{tabular}{l} 
KORESPONDENSI \\
\hline $\begin{array}{l}\text { E-mail Author Korespondensi: } \\
\text { aardy241@gmail.com }\end{array}$ \\
E-mail Co-Author: \\
sony.irw@gmail.com \\
$\underline{\text { humiras.hardi@mercubuana.ac.id }}$
\end{tabular}

\section{A $\mathbf{B} \mathbf{S} \mathbf{T} \mathbf{R}$ A $\mathbf{K}$}

Keselamatan dan kesehatan kerja (K3) merupakan aspek penting dalam mengendalikan semua risiko yang ada didalam operasional proyek konstruksi gedung, sehingga Penerapan K3 ditempat kerja dapat meminimalkan risiko kecelakaan kerja pada setiap kegiatan proses konstruksi dan produksi. Tujuan dari penelitian ini adalah Mengkaji kemungkinan risiko terkait implementasi K3 yang terjadi pada proyek konstruksi gedung berdasarkan penelitian beberapa proyek yang dilakukan sebelumnya. Hal ini berguna bagi pengelola proyek untuk mengantisipasi kemungkinan risiko keselamatan dan kesehatan kerja pada kondisi sekarang, sehingga bisa direncanakan strategi untuk menghadapi risiko tersebut dalam mencapai tujuan dari proyek untuk zero Accident., jurnal dan literatur mengenai risiko K3 pada proyek konstruksi bangunan yang telah dilakukan sebelumnya untuk mengetahui gambaran tentang risiko yang lebih mungkin terjadi dan cara-cara penanganan risiko yang dikembangkan. Dalam studi dilakukan pengelompokan risiko dalam 3 kategori yaitu: Risiko Internal, Risiko Eksternal, dan Risiko Proyek. Hasil kajian literatur ini menunjukkan bahwa Risiko Internal non teknis memiliki dampak terbesar pada proyek konstruksi bangunan gedung di Indonesia dalam kurun waktu 10 tahun terakhir.

\section{PENDAHULUAN}

Proyek pembangunan gedung bertingkat tinggi khususnya dikota besar di Indonesia saat ini merupakan salah satu alternatif pembangunan yang dilakukan dalam rangka mengatasi keterbatasan lahan. Menurut Badan Penyelenggara Jaminan Sosial (BPJS) Ketenagakerjaan mencatat angka kecelakaan kerja di Indonesia cenderung terus meningkat. Tahun 2017 mencapai angka 123.041 kasus kecelakaan kerja. Sedangkan pada tahun 2018 tercatat sebanyak 157.313 kasus kecelakaan kerja, pada 2019 jumlah kecelakaan kerja 114.00 kasus kecelakaan, tahun 2020 meningkat di 177.000 kasus kecelakaan kerja. Santia (2021). Jumlah Kecelakaan Kerja Meningkat di 2020, Capai 177.000 Kasus. Di akses dari https://www.liputan6.com. Tentunya dalam suatu pembangunan proyek khususnya gedung, dibutuhkannya kematangan persiapan dari K3 atau yang biasa disebut Keamanan, Kesehatan, dan Keselamatan Kerja. Manajemen Risiko K3 adalah suatu upaya mengelola risiko untuk mencegah terjadinya kecelakaan yang tidak diinginkan secara komprehensif, terencana dan terstruktur dalam suatu kesisteman yang baik. Keselamatan dan kesehatan kerja merupakan aspek penting dalam mengendalikan semua risiko yang ada didalam operasional perusahaan (Patradhiani, 2013). Kecelakaan yang terjadi di lingkungan kerja sebagian besar $88 \%$ disebabkan karena perilaku yang tidak aman (unsafe action), $10 \%$ kondisi lingkungan kerja yang tidak aman (unsafe condition) dan 2\% tidak diketaui penyebabnya ( Henrich, 1931), Manajemen proyek harus melakukan analisis terhadap manajemen risiko yang diharapkan bisa mengurangi melindungi bahkan menghilangkan risiko kecelakaan kerja (zero accident) pada tenaga kerja.

Berdasarkan permasalahan diatas, maka peneliti mengangkat penelitian ini dengan cara mengumpulkan data penelitian yang ada pada jurnal terdahulu, untuk dapat mengklasifikasikan jenis - jenis risiko yang ada.

Konstruksi bangunan baik bangunan industry, kantor, gedung, adalah untuk memenuhi kebutuhan manusia dalam melakukan aktifitas dan pekerjaan. Dalam hal pembangunan konsruksi bangunan perlu dilakukan penilaian risiko dari berbagai sisi. 
Dalam penelitian ini dilakukan penilaian risiko yang dibagi menjadi 3 (tiga) kelompok (Zavadskas et al. 2010), yaitu:

- Risiko eksternal yaitu: risiko terkait politik, ekonomi, sosial, dan cuaca.

- $\quad$ Risiko proyek (kriteria proses konstruksi) yaitu: risiko terkait waktu, biaya, Kualitas kerja, konstruksi, dan teknologi.

- Risiko internal antara lain: risiko terkait sumber daya, anggota proyek, lokasi konstruksi, dokumen, dan informasi.

Ketiga kategori di atas dibagi menjadi 2 (dua) kategori, yaitu

- Risiko teknis; berkaitan dengan penilaian kemungkinan bahwa sistem yang diwujudkan dalam desain ketika dibangun memenuhi persyaratan kinerja, dan jika terjadi kekurangan kinerja, seberapa serius kekurangannya (Klein \& Cork, 1998). Risiko teknis yang dijelaskan dalam artikel ini meliputi risiko, metode konstruksi, desain konstruksi bangunan, ketersediaan material, kualitas kerja, dan lain-lain.

- Risiko non-teknis; adalah risiko yang dapat mempengaruhi proyek tertentu secara langsung, penyebabnya adalah kejadian yang tidak direncanakan dan tidak diharapkan yang mengakibatkan penyimpangan yang tidak diinginkan dari lokasi pelaksanaan proyek yang dilakukan oleh pemangku kepentingan eksternal (non-kontraktor)

Penelitian ini dilakukan untuk mengetahui seberapa jauh risiko keselamatan Kerja pada proyek kontruksi bangunan gedung di Indonesia selama periode 10 tahun terkahir, kemudian mengelompokan faktor-faktor apa saja yang dapat menyebabkan risiko K3 pada proyek konstruksi yang dapat mengindentifikasi segala risiko keselamatan dalam setiap proyek konstruksi, sehingga dapat dijadikan Panduan untuk dapat mengidentifikasikan resiko Keselamatan dan Kesehatan Kerja
K3) pada kodisi sekarang dan pada kondisi mendatang guna mengurangi angka kecelakaan kerja di Lokasi kerja proyek konstruksi gedung.

\section{METODE}

Studi yang dilakukan dalam penulisan ini yaitu dengan mencari jurnal dan artikel pada sumber yang telah ditentukan dan kemudian memilih jurnal berdasarkan "Keselamatan dan Kesehatan Kerja ", dalam cakupan proyek konstruksi bangunan Gedung yang dilaksanakan pada Konstruksi di Indonesia pada kurun waktu 10 Tahun terakhir. Selanjutnya melakukan diskusi bersama dan menetapkan 40 jurnal dengan membunyikan hasil pada jurnal tepilih tersebut. Kemudian menganalisa tiap jurnal berkaitan Risiko Keselamatan Kerja yang ditinjau adalah risiko teknis dan non teknis baik dari eksternal, internal maupun dari proyek. Berikut adalah kerangka penelitian dalam studi ini.:

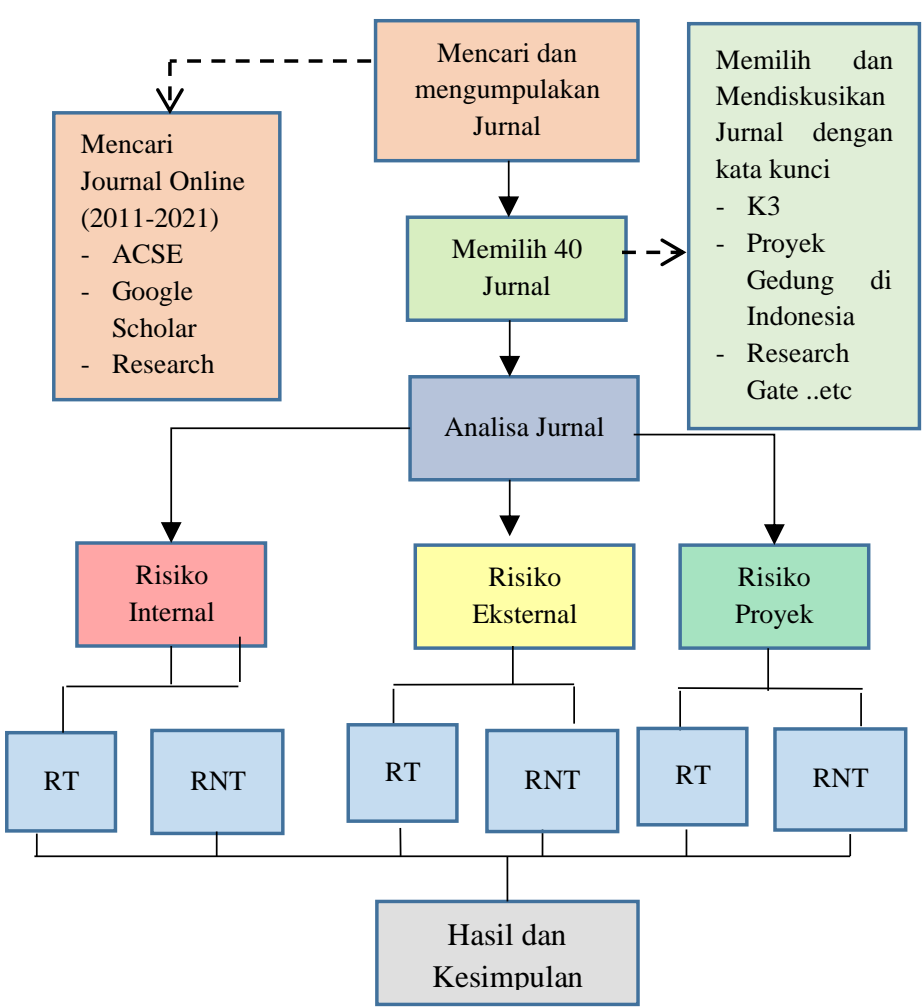

Keterangan: $\mathrm{RT}=$ Risiko Teknis $; \mathrm{RNT}=$ Risiko Non Teknis

Gambar 1. Kerangka Berpikir Penelitian

\section{HASIL DAN DISKUSI}

Table 1. Penelitian Topik Identifikasi Risiko Kesehatan dan Keselamatan Kerja pada Proyek Konstruksi Gedung di Indonesia

\begin{tabular}{|c|c|c|c|c|c|c|c|c|c|}
\hline \multirow{3}{*}{ No } & \multirow{3}{*}{$\begin{array}{c}\text { Identitas } \\
\text { jurnal }\end{array}$} & \multirow{3}{*}{$\begin{array}{c}\text { Wilayah } \\
\text { /kota }\end{array}$} & \multicolumn{6}{|c|}{ Kategori Risiko K3 } & \multirow{3}{*}{ Hasil } \\
\hline & & & \multicolumn{2}{|c|}{ Internal } & \multicolumn{2}{|c|}{ External } & \multicolumn{2}{|c|}{ Proyek } & \\
\hline & & & $\mathbf{T}$ & NT & $\mathbf{T}$ & NT & $\mathbf{T}$ & NT & \\
\hline 1 & $\begin{array}{c}\text { (Sucita \& Broto, } \\
\text { 2011) }\end{array}$ & Jakarta & $\sqrt{ }$ & $\sqrt{ }$ & & $\sqrt{ }$ & & $\sqrt{ }$ & $\begin{array}{l}\text { Penilaian/ pengukuran bahaya/ risiko } \\
\text { dikelompokkan menjadi } 3 \text { kategori/level } \\
\text { risiko yaitu Risiko rendah/ Low risk (L), } \\
\text { Risiko sedang/ Medium risk (M), Risiko }\end{array}$ \\
\hline
\end{tabular}




\begin{tabular}{|c|c|c|c|c|c|c|c|c|c|}
\hline & & & & & & & & & $\begin{array}{l}\text { tinggi/ High risk }(\mathrm{H}) \text {. Berdasarkan } \\
\text { identifikasi dan pengukuran resiko tersebut } \\
\text { kemudian dibuat pengendalian risiko. } \\
\text { Sebanyak } 300 \text { bentuk pengendalian berhasil } \\
\text { di buat untuk menanggulangi risiko-risko } \\
\text { yang ada. }\end{array}$ \\
\hline 2 & $\begin{array}{c}\text { (Safira \& } \\
\text { Ramdhan, 2020) }\end{array}$ & Nasional & & & & $\sqrt{ }$ & & & $\begin{array}{l}\text { Regulasi tentang konstruksi komponen } \\
\text { SMK3 diIndonesia perlu diatur lagi sehingga } \\
\text { mendapatkan regulasi SMK3 yang } \\
\text { komprehensif dan aplikatif untuk mencegah } \\
\text { tumpang tindih regulasi sehingga seluruh } \\
\text { perusahaan konstruksi dapat fokus untuk } \\
\text { memenuhi satu regulasi }\end{array}$ \\
\hline 3 & $\begin{array}{c}\text { (Christina et al., } \\
\text { 2012) }\end{array}$ & Bali & $\sqrt{ }$ & $\sqrt{ }$ & & & & $\sqrt{ }$ & $\begin{array}{l}\text { Model pengaruh budaya keselamatan dan } \\
\text { kesehatan kerja adalah budaya keselamatan } \\
\text { kerja harus dimulai dari top management } \\
\text { terhadap masalah keselamatan kerja, } \\
\text { selanjutnya pelaksanaan konstruksi prosedur } \\
\text { keselamatan kerja memegang peranan } \\
\text { penting dalam meningkatkan kinerja proyek } \\
\text { konstruksi. }\end{array}$ \\
\hline 4 & $\begin{array}{l}\text { (Adityanto \& } \\
\text { Irawan, 2013) }\end{array}$ & Nasional & & & & & & $\sqrt{ }$ & $\begin{array}{l}\text { Menganalisa risiko yang terjadi dan } \\
\text { mengklasifikasikan risiko tersebut kedalam } \\
\text { risiko High, Medium dan Low untuk } \\
\text { dibuatkan mitigasinya }\end{array}$ \\
\hline 5 & $\begin{array}{l}\text { (Alfons Willyam } \\
\text { Sepang Tjakra et } \\
\text { al., 2013) }\end{array}$ & Manado & & & & & & $\sqrt{ }$ & $\begin{array}{l}\text { Menganalisa risiko dengan perkalian } \\
\text { frekuensi risiko dan dampak, dengan hasil } \\
\text { mitigasi adalah penerapan sistem manajemen } \\
\text { risiko K3 }\end{array}$ \\
\hline 6 & $\begin{array}{c}\text { (Priyono \& } \\
\text { Harianto, 2019) }\end{array}$ & Surabaya & $\sqrt{ }$ & $\sqrt{ }$ & & & $\sqrt{ }$ & $\sqrt{ }$ & $\begin{array}{l}\text { Hasil dari penelitian ini Kriteria ketiga } \\
\text { proyek tersebut adalah memuaskan.. } \\
\text { faktor yang mempengaruhi perbedaan dalam } \\
\text { penerapan SMK3 di ketiga proyek tersebut } \\
\text { yaitu faktor perencanaan, faktor perusahaan } \\
\text { kontraktor, faktor kesiapan manajemen, } \\
\text { faktor kesadaran manajemen. }\end{array}$ \\
\hline 7 & $\begin{array}{c}\text { (Soputan et al., } \\
\text { 2014) }\end{array}$ & Manado & & $\sqrt{ }$ & $\sqrt{ }$ & & $\sqrt{ }$ & & $\begin{array}{l}\text { Identifikasi risiko } \mathrm{K} 3 \text {, penilaian risiko } \mathrm{K} 3 \text {, } \\
\text { pengendalian terhadap risiko } \mathrm{K} 3 \text { pada } \\
\text { kegiatan proyek pembangunan infrastruktur } \\
\text { gedung. Metode penilaian menggunakan } \\
\text { matriks penilaian risiko yang bersumber dari } \\
\text { AS/NZS } 4360: 2004 \text {. diperoleh nilai risiko } \\
\text { yang tinggi, yaitu material terjatuh dari } \\
\text { ketinggian dan menimpa pekerja dengan } \\
\text { indeks risiko sebesar } 20 \text { dan penggolongan } \\
\text { risiko pada Very High Risk. }\end{array}$ \\
\hline 8 & $\begin{array}{c}\text { (Wawuru \& } \\
\text { Yuamita, 2016) }\end{array}$ & Yogyakarta & & $\sqrt{ }$ & & & & $\sqrt{ }$ & $\begin{array}{l}\text { faktor yang sangat berpengaruh dalam } \\
\text { terjadinya kecelakaan kerja adalah komitmen } \\
\text { top management dan kesadaran pekerja. } \\
\text { untuk itu dilakukan mitigasi pihak } \\
\text { manajemen bertanggung jawab } \\
\text { mengembangkan dan mempertahankan suatu } \\
\text { program pencegahan terjadinyakecelakaan } \\
\text { kerja dan meningkatkan praktik praktik kerja } \\
\text { dan kondisi yang aman, }\end{array}$ \\
\hline 9 & $\begin{array}{c}\text { (Bondroini et al., } \\
\text { 2012) }\end{array}$ & & & $\sqrt{ }$ & & & & $\sqrt{ }$ & $\begin{array}{l}\text { Hasil data kuesioner tanggapan responden } \\
\text { mengenai faktor-faktor yang mempengaruhi } \\
\text { penerapan SMK3 di lokasi proyek adalah } \\
\text { (X11) yang berarti bahwa sosial, kondisi }\end{array}$ \\
\hline
\end{tabular}




\begin{tabular}{|c|c|c|c|c|c|c|c|}
\hline & & Surabaya & & & & & $\begin{array}{l}\text { ekonomi dan budaya yang kurang kondusif } \\
\text { dan mendapatkan nilai prosentase sebesar } \\
11,830 \% \text { dan (X1) Kurangnya kerjasama, } \\
\text { sosialisasi, koordinasi. antara pegawai/staf } \\
\text { manajemen dengan pekerja dalam } \\
\text { pelaksanaan dan pengawasan program K3 } \\
\text { guna mencapai target zero accident dan } \\
\text { mendapatkan nilai persentase sebesar } \\
8,218 \%\end{array}$ \\
\hline 10 & $\begin{array}{l}\text { (Komponen et } \\
\text { al., 2019) }\end{array}$ & Nasional & & $\sqrt{ }$ & & & $\begin{array}{l}\text { Sebagian besar proyek konstruksi gedung } \\
\text { mencakup seluruh sub komponen kegiatan } \\
\text { pelaksanaan SMK3 konstruksi sebagaimana } \\
\text { tertuang dalam surat edaran dalam kontrak } \\
\text { kerja. }\end{array}$ \\
\hline 11 & $\begin{array}{l}\text { (Sutawijaya et } \\
\text { al., 2017) }\end{array}$ & Bandung & $\sqrt{ }$ & $\sqrt{ }$ & & $\sqrt{ }$ & $\begin{array}{l}\text { Untuk meningkatkan kinerja dalam } \\
\text { manajemen konstruksi, sistem harus } \\
\text { diintegrasikan dengan strategi manajemen } \\
\text { keselamatan yang dikategorikan dalam tiga } \\
\text { sub bidang: organisasi kebijakan struktur, } \\
\text { prosedur dan implementasi. Kesimpulannya, } \\
\text { pelaksanaan proyek ini akan meningkatkan } \\
\text { kinerja dalam kegiatan konstruksi. }\end{array}$ \\
\hline 12 & $\begin{array}{l}\text { (Sigit \& Azizah, } \\
\text { 2019) }\end{array}$ & Yogyakarta & $\sqrt{ }$ & $\sqrt{ }$ & $\sqrt{ }$ & $\sqrt{ }$ & $\begin{array}{l}\text { Hasil penelitian SMK3 pada Proyek "7 in 1" } \\
\text { telah menerapkan SMK3 sesuai PER. } \\
\text { 05/MEN/1996. Namun karenabeberapa } \\
\text { faktor, terdapat kasus-kasus yang } \\
\text { menyebabkan pelaksanaan SMK3 kurang } \\
\text { maksimal, sehingga perlu peningkatan } \\
\text { penerapan SMK3 di lapangan untuk } \\
\text { meminimalisir kecelakaan di lokasi proyek } \\
\text { konstruksi. }\end{array}$ \\
\hline 13 & (Yuliani, 2017) & Nasional & $\sqrt{ }$ & $\sqrt{ }$ & $\sqrt{ }$ & & $\begin{array}{l}\text { Identifikasi risiko pada proyek } \\
\text { pembangunan infrastruktur gedung dengan } \\
\text { hasil risiko tertinggi pada pekerjaan tanah } \\
\text { adalah lifting material dengan service crane } \\
\text { dengan variabel yaitu pekerja dan fasilitas } \\
\text { tertimpa material dengan indeks risiko } \\
\text { sebesar } 5,88 \text {, pekerjaan struktur atas yaitu } \\
\text { lifitng material dengan tower crane dengan } \\
\text { variabel material terjatuh dari ketinggian dan } \\
\text { menimpa pekerja sebesar } 6,63 \text {. }\end{array}$ \\
\hline 14 & $\begin{array}{c}\text { (Saraswati et al., } \\
\text { 2020) }\end{array}$ & Surabaya & $\sqrt{ }$ & $\sqrt{ }$ & $\sqrt{ }$ & & $\begin{array}{l}\text { Pada Proyek Pembangunan Gedung Kuliah } \\
\text { Bersama Kampus C UNAIR memiliki } \\
\text { prosentase } 77,84 \% \text {, sehingga dapat di } \\
\text { klasifikasikan dalam kategori SANGAT } \\
\text { BAIK }\end{array}$ \\
\hline 15 & $\begin{array}{l}\text { (Nadhila et al., } \\
\text { 2018) }\end{array}$ & Malang & $\sqrt{ }$ & $\sqrt{ }$ & $\sqrt{ }$ & v & $\begin{array}{l}\text { Mengidentifikasi risiko-risiko K3 yang } \\
\text { dihadapi serta mengklasifikasi setiap risiko } \\
\text { K3 yang menghambat kinerja Dari analisis } \\
\text { jenis risiko terdapat } 25 \text { variabel dengan } \\
\text { risiko rendah, } 3 \text { variabel dengan risiko } \\
\text { sedang dan } 2 \text { variabel dengan risiko tinggi. } \\
\text { Untuk memperkecil tingkat risiko maka } \\
\text { diperlukan pengendalian risiko dengan cara } \\
\text { engineering, administratif dan alat pelindung } \\
\text { diri. Prosentase kepatuhan pada proyek ini } \\
\text { adalah } 71,87 \% \text {. }\end{array}$ \\
\hline 16 & & & $\sqrt{ }$ & $\sqrt{ }$ & & & $\begin{array}{l}\text { Salah satu variabel yang dikategorikan } \\
\text { tingkat resiko sangat tinggi (Very High Risk) } \\
\text { yaitu variabel menyentuh benda yang tidak }\end{array}$ \\
\hline
\end{tabular}




\begin{tabular}{|c|c|c|c|c|c|c|c|c|c|}
\hline & $\begin{array}{l}\text { (Efendi et al., } \\
\text { 2020) }\end{array}$ & Kediri & & & & & & & $\begin{array}{l}\text { bergerak atau tersandung,untuk tingkat } \\
\text { resiko tinggi (High Risk) diperoleh empat } \\
\text { variabel, untuk tingkat resiko (Medium Risk } \\
\text { ) diperoleh sepuluh variabel dan untuk } \\
\text { tingkat risiko rendah (Low Risk) } 2 \text { variabel. }\end{array}$ \\
\hline 17 & $\begin{array}{l}\text { (Alexander et } \\
\text { al., 2019) }\end{array}$ & Padang & $\sqrt{ }$ & & & & & $\sqrt{ }$ & $\begin{array}{l}\text { Pada pekerjaan balok dan pelat proyek } \\
\text { konstruksi bangunan gedung bahaya yang } \\
\text { dapat diidentifikasi adalah terjatuh, terjepit, } \\
\text { tertusuk, tergores, tertimpa, terhirup debu, } \\
\text { tersandung, tersengat listrik. Penilaian resiko } \\
\text { berkisar antara } 16-20 \text { dengan tingkat resiko } \\
\text { ekstrim yang beresiko kematian dan cacat. } \\
\text { Dan ada penilaian resiko } \leq 6 \text { dengan tingkat } \\
\text { resiko sedang yang beresiko cedera. }\end{array}$ \\
\hline 18 & $\begin{array}{c}\text { (Fauzania et al., } \\
\text { 2019) }\end{array}$ & Nasional & $\sqrt{ }$ & $\sqrt{ }$ & $\sqrt{ }$ & & $\sqrt{ }$ & & $\begin{array}{l}\text { Bahwa tidak semua pekerja memahami } \\
\text { pentingnya kesehatan dan keselamatan } \\
\text { Pekerja jarang memakai pakaian pelindung } \\
\text { bahkan untuk keselamatan mereka sendiri. }\end{array}$ \\
\hline 19 & $\begin{array}{l}\text { (Pesa \& Hendra, } \\
\text { 2017) }\end{array}$ & Pekanbaru & & $\sqrt{ }$ & $\sqrt{ }$ & $\sqrt{ }$ & & & $\begin{array}{l}\text { Penilaian audit SMK3 untuk proyek } \\
\text { pembangunan Living World Pekanbaru telah } \\
\text { mencapai } 94 \% \text { dan pada kategori PUAS. } \\
\text { Implementasi SMK3 mencapai } 71,49 \% \\
\text { termasuk dalam kategori BAIK. }\end{array}$ \\
\hline 20 & $\begin{array}{c}\text { (Jawat \& } \\
\text { Suwitanujaya, } \\
\text { 2018) }\end{array}$ & Nasional & $\sqrt{ }$ & $\sqrt{ }$ & $\sqrt{ }$ & $\sqrt{ }$ & & & $\begin{array}{l}\text { Perencanaan sistem manajemen keselamatan } \\
\text { dan keselamatan kerja merupakan rangkaian } \\
\text { dari beberapa tahapan yaitu, identifikasi } \\
\text { bahaya, penilaian resiko, pengendalian } \\
\text { resiko, dan perhitungan biaya dari } \\
\text { pengendalian resiko tersebut. biaya yang } \\
\text { dibutuhkan untuk pencegahan (prevention } \\
\text { cost) dan biaya pengawasan (inspection cost) } \\
\text { kecelakaan kerja sebesar Rp 726.182.726,28 } \\
\text { atau } 5.39 \% \text { dari total nilai kontrak }\end{array}$ \\
\hline 21 & $\begin{array}{c}\text { (Tagueha WP et } \\
\text { al., 2018) }\end{array}$ & Nasional & $\sqrt{ }$ & $\sqrt{ }$ & $\sqrt{ }$ & & & & 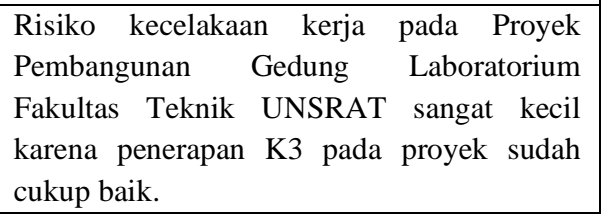 \\
\hline 22 & (Science, 2021) & Jakarta & $\sqrt{ }$ & & & & & $\sqrt{ }$ & $\begin{array}{l}\text { Aspek yang paling mungkin menyebabkan } \\
\text { kecelakaan/kegagalan Keselamatan dan } \\
\text { Kesehatan Kerja adalah aspek sumber daya } \\
\text { manusia dengan score }: 0.47 \text {, peristiwa yang } \\
\text { tak terduga dengan score : } 0.298 \text {,aspek } \\
\text { teknik dengan score }: 0.232\end{array}$ \\
\hline 23 & $\begin{array}{l}\text { (Risiko et al., } \\
\text { n.d, 2017) }\end{array}$ & Batam & $\sqrt{ }$ & $\sqrt{ }$ & & & & & $\begin{array}{l}\text { Terdapat } 5 \text { pekerjaan yang diamati pada } \\
\text { proyek pembangunan Menara X di Jakarta } \\
\text { Didapatkan level risiko rendah untuk } \\
\text { pekerjaan pasangan bata ringan dan } \\
\text { pekerjaan dinding lapis plester, didapatkan } \\
\text { level risiko sedang untuk pekerjaan dinding } \\
\text { partisi gypsum, untuk pekerjaan pasangan } \\
\text { kaca dan pekerjaan tangga didapatkan level } \\
\text { risiko tinggi }\end{array}$ \\
\hline 24 & $\begin{array}{c}\text { (Hati \& Ningsih, } \\
\text { 2019) }\end{array}$ & Nasional & $\sqrt{ }$ & $\sqrt{ }$ & & & & & $\begin{array}{l}\text { Setelah dilakukan identifikasi terdapat potensi } \\
\text { bahaya namun dengan rata-rata potensi bahaya } \\
\text { (risk level) resiko sedang dan kemungkinan } \\
\text { memerlukan kendali resiko, analisis potensi } \\
\text { bahaya ternyata dapat menurunkan resiko } \\
\text { kecelakaan kerja, }\end{array}$ \\
\hline
\end{tabular}




\begin{tabular}{|c|c|c|c|c|c|c|c|c|c|}
\hline 25 & $\begin{array}{c}\text { (Endroyo et al., } \\
\text { 2016) }\end{array}$ & Padang & $\sqrt{ }$ & & & & $\sqrt{ }$ & $\sqrt{ }$ & $\begin{array}{l}\text { Hasil penelitian dari } 57 \text { proyek gedung } \\
\text { bertingkat menengah melalui purposive } \\
\text { sampling adalah: (i) Penerapan SMK3 pada } \\
\text { konstruksi di beberapa kota di Indonesia } \\
\text { termasuk dalam "tingkat hijau" (85\% - } \\
100 \%) \text {. }\end{array}$ \\
\hline 26 & $\begin{array}{l}\text { (Teknik et al., } \\
\text { 2021) }\end{array}$ & Pontianak & $\sqrt{ }$ & $\sqrt{ }$ & $\sqrt{ }$ & & & & $\begin{array}{l}\text { Level risiko tinggi (high) (59\%) diperoleh } 10 \\
\text { (sepuluh) jenis resiko, yaitu pekerja atau alat } \\
\text { berat jatuh kedalam galian, mata tekena } \\
\text { percikan api dan asap, alat berat menabrak } \\
\text { fasilitas sekitar, tangan terjepit ketika } \\
\text { pembengkokanbesi, gangguan pernafasan } \\
\text { akibat debu pasir dan semen }\end{array}$ \\
\hline 27 & $\begin{array}{c}\text { (Ohsas, n.d, } \\
\text { 2018) }\end{array}$ & Nasional & $\sqrt{ }$ & $\sqrt{ }$ & & $\sqrt{ }$ & & & $\begin{array}{l}\text { Metode OHSAS } 18001 \text { yang dimulai dengan } \\
\text { melakukan analisis kecelakaan yang } \\
\text { mungkin terjadi, dan penyebab kecelakaan } \\
\text { dari tiga faktor utama adalah faktor manusia, } \\
\text { faktor pekerjaan dan metode pelaksanaan, } \\
\text { dan faktor lingkungan }\end{array}$ \\
\hline 28 & $\begin{array}{l}\text { (Manurung, } \\
\text { 2020) }\end{array}$ & Malang & $\sqrt{ }$ & $\sqrt{ }$ & & & $\sqrt{ }$ & & $\begin{array}{l}\text { Perencanaan program K3 pada pekerja } \\
\text { konstruksi dapat memberi pengaruh pada } \\
\text { kinerja dan loyalitas pekerjanya pada proyek } \\
\text { serta menghindarkan proyek dari tundaan } \\
\text { jadwal proyek akibat kecelakaan kerja }\end{array}$ \\
\hline 29 & $\begin{array}{c}\text { (Nugroho et al., } \\
\text { 2018) }\end{array}$ & Nasional & $\sqrt{ }$ & $\sqrt{ }$ & & & & & $\begin{array}{l}\text { Hasil risiko paling tinggi (very hight Risk) } \\
\text { sebanyak } 14 \text { sub variabel dari variabel } \\
\text { pekerja, peralatan, metode, dan lingkungan } \\
\text { kerja. Untuk risiko tinggi (Hight Risk) } \\
\text { sebanyak } 4 \text { sub variabel dari variabel pekerja } \\
\text { dan metode kerja. Sedangkan untuk risiko } \\
\text { sedang (Medium Risk) sebanyak } 2 \text { sub } \\
\text { variabel dari variabel peralatan dan } \\
\text { lingungan kerja. Dari beberapa metode } \\
\text { pengendalian risiko, dipilih pengendalian } \\
\text { secara administratif, eleminasi dan } \\
\text { penggunaan APD. }\end{array}$ \\
\hline 30 & (Kerja, 2019) & Nasional & $\sqrt{ }$ & $\sqrt{ }$ & $\sqrt{ }$ & & & & $\begin{array}{l}\text { Data mengenai perusahaan sesuai hasil } \\
\text { penilai dan verifikasi yang dilakukan } \\
\text { pengawasan ketenagakerjaan dan } \\
\text { transmigrasi Provinsi Kalimanatan Timur, } \\
\text { bahwa Perusahaan PD Kota Balikpapan telah } \\
\text { memenuhi syarat dan layak untuk } \\
\text { mendapatkan penghargaan atas prestasinya } \\
\text { dalam melaksanakan program Norma } \\
\text { Keselamatan dan Kesehatan Kerja (K3) di } \\
\text { lingkungan kerjanya. }\end{array}$ \\
\hline 31 & $\begin{array}{c}\text { (Nurainiyah \& } \\
\text { Agustapraja, } \\
\text { 2019) }\end{array}$ & Lamongan & & $\sqrt{ }$ & & & $\sqrt{ }$ & $\sqrt{ }$ & $\begin{array}{l}\text { Proyek telah mengimplementasikan K3 } \\
\text { dengan baik, meskipun masih terdapat } \\
\text { beberapa kendala dalam pelaksanaannya. } \\
\text { Kuesioner uji valid dan reliabel dengan } \\
\text { Cronbach Alpha berkisar antara } 0,617-0,867 \\
\text { yang berarti lebih besar dari } 0,60 \text {. }\end{array}$ \\
\hline 32 & $\begin{array}{c}\text { (Mahendra et al., } \\
\text { 2019) }\end{array}$ & Surabaya & & $\sqrt{ }$ & & & & $\sqrt{ }$ & $\begin{array}{l}\text { Terdapat pengaruh yang positif pengetahuan } \\
\mathrm{K} 3 \text { terhadap kesadaran berperilaku K3 } \\
\text { dengan bukti nilai } t \text { hitung }>\mathrm{t} \text { tabel }(3,765> \\
2,032) \text { Terdapat pengaruh positif sikap } \\
\text { terhadap kesadaran berperilaku K3 dengan } \\
\text { bukti } t \text { hitung }>\mathrm{t} \text { tabel }(2,134>2,032) \text {. } \\
\text { Terdapat pengaruh positif pengetahuan dan } \\
\text { sikap secara bersama-sama terhadap }\end{array}$ \\
\hline
\end{tabular}




\begin{tabular}{|c|c|c|c|c|c|c|c|c|}
\hline & & & & & & & & $\begin{array}{l}\text { kesadaran berperilaku K3 dengan bukti } \\
\text { Fhitung }>\text { Ftabel }(23,093>3,28)\end{array}$ \\
\hline 33 & $\begin{array}{l}\text { (Pasarong et al., } \\
\text { 2021) }\end{array}$ & Makasar & & $\sqrt{ }$ & & $\sqrt{ }$ & $\sqrt{ }$ & $\begin{array}{l}\text { Kendala pada penerapan Keselamatan \& } \\
\text { Kesehatan Kerja ialah kurangnya kesadaran } \\
\text { dan pengetahuan pekerja tentang } \\
\text { Keselamatan dan Kesehatan Kerja (K3). } \\
\text { Selain itu perusahaan juga kurang } \\
\text { konsisten dalam menerapkan Keselamatan } \\
\text { dan Kesehatan Kerja. }\end{array}$ \\
\hline 34 & $\begin{array}{l}\text { (U. S. Lestari, } \\
\text { 2018) }\end{array}$ & Tenggarong & $\sqrt{ }$ & $\sqrt{ }$ & & $\sqrt{ }$ & & $\begin{array}{l}\text { Porsentase biaya pelaksanaan SMK3 sebesar } \\
1.5 \% \text { dari nilai kontrak Rp.30,132,530,000. } \\
\text { Perhitungan pembiayaan SMK3 dapat } \\
\text { digunakan sebagai acuan dalam } \\
\text { melaksanakan program SMK3 di proyek. }\end{array}$ \\
\hline 35 & $\begin{array}{l}\text { (Susilowati et } \\
\text { al., 2021) }\end{array}$ & Nasional & $\sqrt{ }$ & $\sqrt{ }$ & & $\sqrt{ }$ & & $\begin{array}{l}\text { Persepsi pekerja menemukan bahwa } 95,2 \% \\
\text { menyatakan perusahaan mereka telah } \\
\text { memberikan informasi K3 dengan benar. } \\
83 \% \text { mengatakan perusahaan mereka } \\
\text { menerapkan faktor pendukung K3 (reward, } \\
\text { informasi, aturan, dan engagement). }\end{array}$ \\
\hline 36 & $\begin{array}{l}\text { (Restuputri et } \\
\text { al., 2015) }\end{array}$ & Malang & $\sqrt{ }$ & $\sqrt{ }$ & $\sqrt{ }$ & & & $\begin{array}{l}\text { Identifikasi kecelakaan kerja, dilanjutkan } \\
\text { dengan pencarian sumber potensi bahaya di } \\
\text { tempat kerja untuk dilakukan pencegahan } \\
\text { dengan menggunakan Hazard and } \\
\text { Operability Study (HAZOP),ditemukan } \\
\text { sembilan sumber potensi bahaya, seperti: } \\
\text { kondisi kerja, pecahan kaca, sikap pekerja, } \\
\text { panel listrik, kabel kendor, udara panas, } \\
\text { genangan air dan bahan kimia berbahaya, }\end{array}$ \\
\hline 37 & $\begin{array}{c}\text { (Hidayat \& } \\
\text { Siswoyo, 2020) }\end{array}$ & Sidoarjo & & & & & $\sqrt{ }$ & $\begin{array}{l}\text { Ditemukan bahwa resiko yang paling } \\
\text { dominan dan paling berpengaruh terhadap } \\
\text { pembangunan Perumahan Dua Lantai di } \\
\text { Sidoarjo adalah resiko manajemen }\end{array}$ \\
\hline 38 & $\begin{array}{l}\text { (Lestari et al., } \\
\text { 2020) }\end{array}$ & Nasional & & $\sqrt{ }$ & & $\sqrt{ }$ & & $\begin{array}{l}\text { Dua iklim keselamatan kerja di Indonesia } \\
\text { baru juga terungkap: kontradiksi antara } \\
\text { komunikasi manajemen dan praktik } \\
\text { manajemen; kontradiksi antara kepedulian } \\
\text { pekerja terhadap keselamatan dan rendahnya } \\
\text { rasa tanggung jawab pribadi dan } \\
\text { pemberdayaan mereka untuk bertindak } \\
\text { mengurangi risiko }\end{array}$ \\
\hline 39 & $\begin{array}{l}\text { (Sari et al., } \\
\text { 2016) }\end{array}$ & Nasional & & & & & $\sqrt{ }$ & $\begin{array}{l}\text { Analisa resiko tertinggi yaitu pada pekerjaan } \\
\text { instalasi formwork (bekisting) dengan resiko } \\
\text { terjatuh dari ketinggian dengan nilai resiko } \\
\text { sebesar } 232,18\end{array}$ \\
\hline 40 & $\begin{array}{c}\text { (Anwar et al., } \\
\text { 2016) }\end{array}$ & Bandung & & & & & $\sqrt{ }$ & $\begin{array}{l}\text { Risiko Keselamatan Kerja yang paling sering } \\
\text { muncul adalah risiko tertimpa benda dari } \\
\text { atas }(24 \%)\end{array}$ \\
\hline
\end{tabular}

Keterangan $(\sqrt{ })=$ Dibahas, $\mathrm{T}=$ Teknis, NT $=$ Non Teknis

Kajian Jurnal ini dibuat di Indonesia dengan periode Kajian antara 2011-2021 dengan tujuan mengidentifikasi risiko sistem keselamatan kerja yang ada pada proyek gedung di Indonesia seperti pada penelitian (Sucita \& Broto, 2011), penelitian tersebut dilakukan pada proyek Centro City Residence berlokasi di Jakarta mengidentifikasikan penilaian/pengukuran bahaya/risiko dikelompokkan menjadi 3 Kategori. (Safira \& Ramdhan, 2020), jurnal ini dibuat di Indonesia dengan tinjauan bangunan gedung yang dikerjakan secara umum di Indonesia, menyatakan bahwa Sebanyak 30 proyek konstruksi gedung telah menerapkan SMK3. Jurnal ini dibuat pada studi kasus beberapa
Proyek di Bali yang dilaksanakan Oleh PT.Tunas Jaya Sanur,Bali menyatakan Komitmen Top Management Terhadap K3 berpengaruh significant terhadap variable kinerja proyek (Christina et al., 2012), penelitian (Adityanto \& Irawan, 2013) yang dilakukan tinjauan secara umum Konstruksi Gedung bahwa identifikasi dan penilaian resiko Keselamatan kerja ditemukan bahwa pekerjaan struktur atas memiliki risiko lebih banyak dan rata-rata indeks risiko lebih besar dari struktur bawah.

Jurnal (Alfons Willyam Sepang Tjakra et al., 2013) yang diteliti pada proyek Pembangunan ruko Orlens Fashion di Manado, diperoleh Penilaian Kriteria kecelakaan kerja tertinggi dan faktor penyebab adalah Terjatuhnya pekerja paling tinggi 
adalah faktor manusia dengan tidak memakai Alat Pelindung diri ( APD). Pada penelitian (Priyono \& Harianto, 2019) Studi kasus Pada proyek Gedung di Surabaya bahwa terdapat 4 faktor yang menpengaruhi perbedaan dalam penerapan SMK3 di proyek Gedung yaitu faktor perencanaan, faktor perusahaan kontraktor, faktor kesiapan manajemen, faktor kesadaran manajemen, Studi kasus Pembangunan gedung SMA Eben Haezar di manado (Soputan et al., 2014) menyatakan bahwa nilai risiko yang tinggi, yaitu material terjatuh dari ketinggian dan menimpa pekerja. Pada Jurnal (Wawuru \& Yuamita, 2016) yang melakukan penelitian pada Proyek Pembangunan Apartment Student Castle di Yogyakarta, menganalisa Faktor yang paling signifikan mempengaruhi terjadinya kecelakaan kerja adalah Komitmen Perusahaan dan Kesadaran Pekerja.

(Bondroini et al., 2012) pada studi kasus Proyek Pembangunan Mall di Surabaya, menyatakan bahwa proyek tersebut telah menerapkan Kebijakan Mutu \& Sistem Manajemen Keselamatan dan Kesehatan (SMK3) K3L baik perencanaan dan pelaksanaan dikelola dengan baik. Pada jurnal lain (Komponen et al., 2019) menyatakan bahwa Sebanyak 30 proyek konstruksi gedung di Indonesia telah menerapkan SMK3 dengan mencantumkan rincian pelaksanaan SMK3 konstruksi. Pada studi kasus dalam proyek Arcamanik Bandung menyatakan bahwa untuk meningkatkan kinerja dalam manajemen konstruksi, sistem harus diintegrasikan dengan strategi manajemen keselamatan yang dikategorikan dalam tiga sub bidang: organisasi kebijakan struktur, prosedur dan implementasi (Sutawijaya et al., 2017). Pada Proyek Pembangunan gedung proyek “ 7 in 1" Universitas Negri Yogyakarta dalam Penelitian (Sigit \& Azizah, 2019) bahwa Penerapan SMK3 Pada proyek tersebut, namun terdapat faktorfaktor yang menyabakan kasus di proyek yang mengakibat kurang maksimal.

Pada Jurnal (Yuliani, 2017) secara umum untuk proyek gedung bertingkat diperoleh resiko tertinggi terkait kesematan kerja pada pekerjaan tanah dan struktur atas adalah lifting material dengan pelayanan atau service Crane ( alat berat) dengan resiko kejatuhan material. Untuk studi kasus Proyek Pembangunan Gedung kuliah kampus C Unair Surabaya pada penelitian (Saraswati et al., 2020) menyatakan bahwa tindakan penerapan Keselamatan dan Kesehatan Kerja ( K3) yang paling dominan yaitu Pengecekan APD dan Penyediaan APD. Pada penelitian (Nadhila et al., 2018) studi kasus Pembangunan Gedung Fakultas Pertanian Universitas Brawijaya Malang, bahwa menIndentifikasi risiko K3 serta Klasifikasi setiap risiko $\mathrm{K} 3$ mampu mengendalikan dan memperkecil risiko K3 tersebut dengan cara engineering, administrative dan Alat pelindung diri.

Pada jurnal (Efendi et al., 2020) Proyek Gedung Universitas LP3M Kediri mengkaji tentang identifikasi, penilaian risiko K3, dan cara pengendalian risiko K3. Proyek Pasar atas Bukit Tinggi Padang diidentifikasi bahaya, menilai resiko serta merencanakan pengendalian Resiko K3 merupakan hasil kajian (Alexander et al., 2019). Penelitian (Fauzania et al., 2019) mengidentifikasi kesadaran pekerja khususnya pekerja konstruksi mengenai standar kesehatan dan keselamatan kerja untuk Proyek Gedung secara umum. Studi kasus Pembangunan Gedung Living World- Pekanbaru (Pesa \& Hendra, 2017) menyatakan bahwa faktor-faktor yang menghambat penerapan SMK3 hanya terdapat pada faktor psikologi pekerja. Dan pada Jurnal (Jawat \& Suwitanujaya, 2018) Secara umum Resiko kecelakaan kerja dapat mengganggu produktifitas, kesehatan, dan kualitas tenaga kerja, maka perlu adanya manajemen yang baik.

(Tagueha WP et al., 2018) yang melakukan penelitian pada proyek pembangunan gedung laboratorium Faklutas Teknik UNSRAT menyatakan adanya hubungan yang kuat dan positif antara penerapan keselamatan dan kesehatan kerja terhadap manajemen risiko dalam Proyek Pembangunan Gedung Laboratorium UNSRAT. Pada jurnal (Science, 2021) dalam penelitiannya menyatakan bahwa aspek yang paling mungkin menyebabkan kecelakaan/kegagalan Keselamatan dan Kesehatan Kerja adalah aspek sumber daya manusia dengan score : 0.47 , peristiwa yang tak terduga dengan score : 0.298 ,aspek teknik dengan score : 0.232. Penelitian (Risiko et al., n.d, 2017) yang dilakukan di Proyek Pembangunan Menara $\mathrm{X}$ di Jakarta mengkonfirmasi bahwa terdapat risiko dengan tingkat rendah yaitu pada pekerjaan pasangan bata ringan, risiko dengan level sedang ada pada pekerjaan pemasangan dinding partisi gypsum dan risiko dengan level tinggi ada pada pekerjaan pemasangan kaca dan pekerjaan tangga. (Hati \& Ningsih, 2019) Dalam penelitian yang dilakukan di PT. Cladtek Bi-Metal Manufacturing, pada proses pekerjaan Hydrotest Manual mengkonfirmasi bahwa terdapat potensi bahaya dengan rata-rata bahaya resiko sedang, JSA dapat menurunkan resiko kecelakaan kerja, potensi kecelakaan kerja jarang terjadi, dapat mengendalikan resiko dimasa yang akan datang, pemantauan dan evaluasi baik.

(Endroyo et al., 2016) mengkonfirmasi bahwa Hasil penelitian dari 57 proyek gedung bertingkat menengah melalui purposive sampling adalah: (i) Penerapan SMK3 pada konstruksi di beberapa kota di Indonesia termasuk dalam "tingkat hijau" (85\% - 100\%).

(Nugroho et al., 2018) melakukan penelitian pada Proyek Pembangungan Gedung Asrama Haji Padang Pariaman dan menyatakan dalam penelitianya terdapat 10 jenis risiko yaitu pekerja atau alat berat jatuh kedalam galian, mata tekena percikan api dan asap, alat berat menabrak fasilitas sekitar, tangan terjepit ketika pembengkokanbesi, gangguan pernafasan akibat debu pasir dan semen. (Yahya.R., 2018) mengkonfirmasi dalam penelitianya factor-faktor yang penyebab kecelakaan kerja yang akan diuraikan dalam identifikasi ini antara lain adalah faktor manusia, factor jenis pekerjaan dan metode pelaksanan, serta faktor lingkungan. Dalam jurnal (Manurung, 2020) menyatakan bahwa perencanaan program K3 pada pekerja konstruksi dapat memberi pengaruh pada kinerja dan loyalitas pekerjanya pada proyek serta menghindarkan proyek dari tundaan jadwal proyek akibat kecelakaan kerja. (Taufiq et al., 2019) melakukan penelitian di perusahaan PD kota Balikpapan menyatakan Penerapan SMK3 jelas dapat mendukung peningkatan kinerja karyawan di perusahaan hal ini terbukti dengan diperolehnya penghargaan atas prestasinya dalam melaksanakan program Norma Keselamatan dan Kesehatan Kerja (K3) di lingkungan kerjanya.

(Nurainiyah \& Agustapraja, 2019) studi kasus Pembangunan Gedung Kantor Pemkab Lamongan menyatakan bahwa proyek telah mengimplementasikan K3 dengan baik ini dibuktikan dengan uji valid dan reliabel dengan Cronbach Alpha berkisar antara 0,617-0,867 yang berarti lebih besar dari 0,60. (Mahendra et al., 2019) mengkonfirmasi bahwa terdapat pengaruh positif pengetahuan K3 \& sikap K3 terhadap kesadaran berperilaku K3. (Pasarong et al., 2021) yang melakukan penelitian di proyek Renovasi Gedung Lembaga Penjamin Mutu Pendidikan (LPMP) Sulawesi Selatan menyatakan bahwa kendala pada 
penerapan Keselamatan \& Kesehatan Kerja ialah kurangnya kesadaran dan pengetahuan pekerja tentang Keselamatan dan Kesehatan Kerja (K3). Selain itu perusahaan juga kurang konsisten dalam menerapkan Keselamatan dan Kesehatan Kerja. Pada penelitian (U. S. Lestari, 2018) yang melakukan penelitian di proyek bangunan Gedung SMPN 1 Tenggarong Kalimantan Timur Porsentase biaya pelaksanaan SMK3 sebesar $1.5 \%$ dari nilai kontrak Rp.30,132,530,000. Perhitungan pembiayaan SMK3 dapat digunakan sebagai acuan dalam melaksanakan program SMK3 di proyek. (Susilowati et al., 2021) mengkonfirmasi bahwa $95,2 \%$ perusahaan tempat mereka bekerja telah memberikan informasi K3 dengan benar dan $83 \%$ mengatakan perusahaan mereka menerapkan factor pendukung K3.

(Restuputri et al., 2015) mengkonfirmasi dalam penelitianya bahwa ditemukan sembilan sumber potensi bahaya, seperti: kondisi kerja, pecahan kaca, sikap pekerja, panel listrik, kabel kendor, udara panas, genangan air dan bahan kimia berbahaya. Di penelitian yang lain (Hidayat \& Siswoyo, 2020) mengkonfirmasi bahwa resiko yang paling dominan dan paling berpengaruh terhadap pembangunan Perumahan Dua Lantai di Sidoarjo adalah resiko manajemen. (Lestari et al., 2020) dalam jurnalnya menemukan bahwa adanya kontradiksi antara komunikasi manajemen dan praktik manajemen; kontradiksi antara kepedulian pekerja terhadap keselamatan dan rendahnya rasa tanggung jawab pribadi dan pemberdayaan mereka untuk bertindak mengurangi risiko. (Sari et al., 2016) menemukan bahwa resiko tertinggi ada pada pekerjaan instalasi formwork (bekisting) dengan resiko terjatuh dari ketinggian dengan nilai resiko sebesar 232,18. (Anwar et al., 2016) menyatakan dalam penelitianya bahwa Risiko Keselamatan Kerja yang paling sering muncul adalah risiko tertimpa benda dari atas dengan persentase sebesar $24 \%$

Dari hasil diskusi dan analis pada kajian jurnal tersebut dapat dikelompokan berdasarkan tahun penerbitan jurnal sebagai berikut:

\section{Tabel Pengelompokan Tinjauan Jurnal}

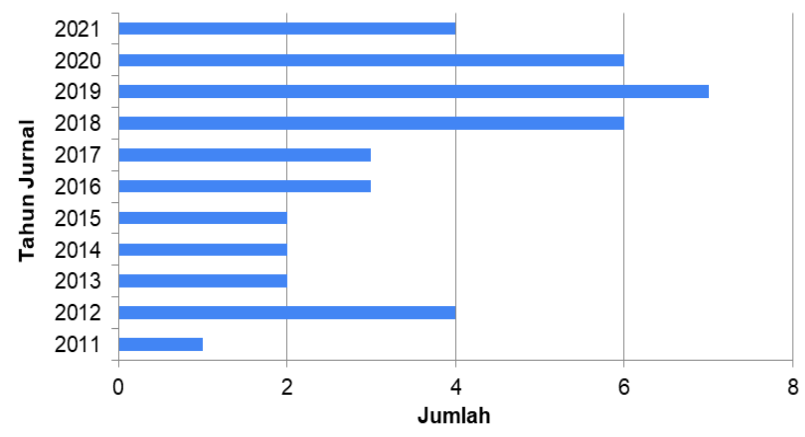

Gambar 2. Pengelompokkan jurnal berdasarkan tahun

Sedangkan Analisa Pada pembahasan terkait analisa risiko Keselamatan dan kesehatan kerja yang dikelompokkan pada masing-masing Tinjauan Jurnal yaitu risiko teknis dan non teknis baik dari eksternal, internal maupun dari proyek dapat dilihat pada gambar 3
Analisa Risiko K3 Proyek Gedung-Kajian Jurnal

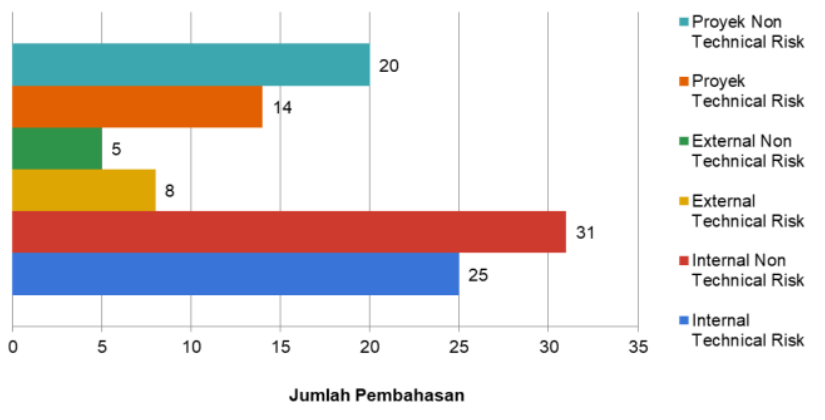

Gambar 3. Bar chart analisis risiko keselamatan dan Kesehatan Kerja pada proyek konstruksi Gedung

Dari tabel tinjauan risiko keselamatan dan kesehatan kerja (K3) dari beberapa literatur proyek gedung diperoleh analisa terbesar adalah risiko internal dengan non teknis, yang merupakan risiko terkait sumber daya, anggota proyek, lokasi konstruksi, dokumen, dan informasi. dimana salah satu risiko tersebut merupakan perilaku SDM, untuk non teknis nya risiko yang dapat mempengaruhi proyek tertentu secara langsung, penyebabnya adalah kejadian yang tidak direncanakan dan tidak diharapkan yang mengakibatkan penyimpangan. Saat ini dunia telah memasuki era revolusi industri 4.0, tidak terkecuali Indonesia. Berbagai teknologi yang menandai dimulainya revolusi industri 4.0 dan menyongsong industri 5.0, Revolusi industri keempat ini akan melibatkan perubahan sistemik di banyak sektor dan aspek kehidupan manusia. Sekarang ini industri dan sektor proyek di Indonesia berada di tahap pengembangan Industri 4.0 dengan otomatisasi dan implementasi dari generasi ini. Dengan otomatisasi tersebut pula, peluang bagi penerapan K3 di perusahaan dan proyek pun akan jauh lebih advance. Penerapan K3 pada revolusi Industri 4.0 masih menghadapi banyak tantangan, salah satunya adalah kesiapan tenaga kerja dalam menghadapi digitalisasi. Perubahan tersebut akan menimbulkan penyesuaian dan peningkatan kompetensi. Strategi yang efektif, efisien serta inovatif dalam mencegah terjadinya kecelakaan dan penyakit akibat kerja. Nantinya, menyongsong perubahan dari industri 4.0 menjadi 5.0 supaya terciptanya keselamatan kerja yang efektif bagi semua pekerja yang ada di indonesia. Perlu kajian lebih mendalam terkait risiko-risiko yang berkembang pada indsutri konstruksi dan mampu menciptakan inovasi-inovasi terkait Keselamatan dan Kesehatan Kerja (K3) yang lebih maju tinkatanya. Saran untuk penelitian lanjutan, perlu nya kajian risiko tersebut di industry 4.0 dan 5.0, seperti Kompetensi SDM - Safety officer di area kerja terkait perkembangan teknologi, Penerapan ISO 45001 dan impactnya ke risiko k3, Aplikasi pintar penunjang aktifitas K3 serta assessment Pekerja secara mandiri yang bisa dilakukan secara instan dan tidak lain tujuannya adalah meminimalisir kecelakan kerja. Gambaran singkat dapat dilihat pada gambar 4 


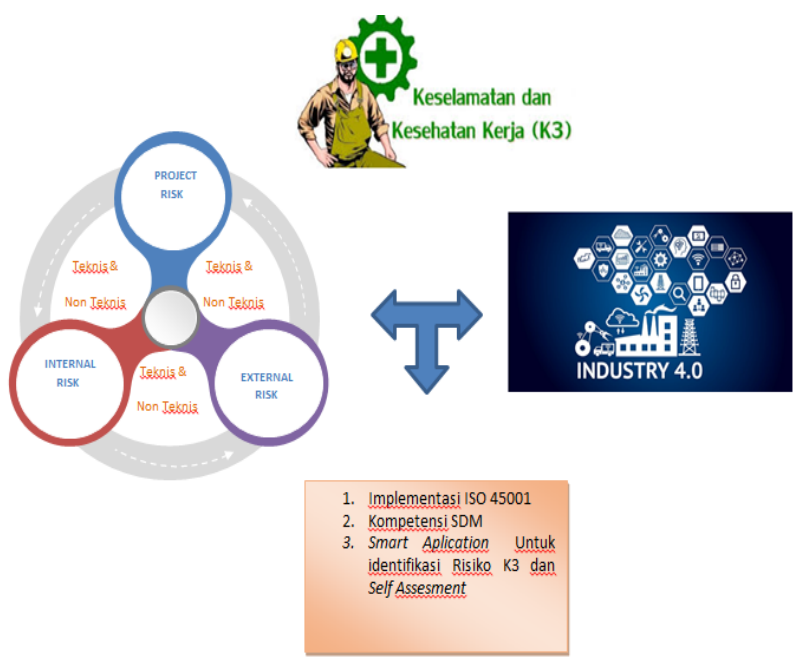

Gambar 4. Alur Penelitian Selanjutnya

\section{KESIMPULAN}

Berdasarkan review hasil kajian Jurnal terkait risiko Keselamatan dan Kesehatan Kerja(K3) pada Konstruksi gedung di Indonesia pada periode 10 tahun terakhir dapat disimpulkan bahwa identifikasi faktor risiko keselamatan pada proyek konstruksi Bangunan bahwa kategori risiko internal non teknis memiliki nilai yang tinggi. Hal ini dapat dijadikan dasar untuk merencanakan mitigasi proyek-proyek selanjutnya terkait risiko Keselamatan dan Kesehatan Kerja (K3) di Indonesia. Manfaat lain bagi penelitian lanjutan untuk dapat mengklasifikasikan risiko K3 pada objek konstruksi lainnya pada era industri 4.0 sehingga diperoleh inovasi yang lebih tinggi tingkatannya.

\section{DAFTAR PUSTAKA}

Abd El-Karim, M. S. B. A., Mosa El Nawawy, O. A., \& AbdelAlim, A. M. (2017). Identification and assessment of risk factors affecting construction projects. HBRC Journal, 13(2), 202-216.

https://doi.org/10.1016/j.hbrcj.2015.05.001

Adityanto, B., \& Irawan, S. (2013). Manajemen Risiko Keselamatan Dan Kesehatan Kerja (K3) Pada Pekerjaan Struktur Bawah Dan Struktur Atas Gedung Bertingkat. Jurnal Karya Teknik Sipil, 2(4), 73-84. http://ejournals1.undip.ac.id/index.php/jkts/article/view/3925\%0Ahttps: //ejournal3.undip.ac.id/index.php/jkts/article/view/3926

Akinbile, B. ., Ofuyatano, M., Oni, O. ., \& Agboola, O. . (2018). Risk Management and Its Influence on Construction Project in Nigeria. Annals of the Faculty of Engineering Hunedoara - International Journal of Engineering, 16(3), 169-174.

Al-Ajmi, H. F., \& Makinde, E. (2018). Risk Management in Construction Projects. Journal of Advanced Management Science, $6(2)$

113-116. https://doi.org/10.18178/joams.6.2.113-116

Alexander, H., Nengsih, S., \& Guspari, O. (2019). Kajian Keselamatan dan Kesehatan Kerja ( K3 ) Konstruksi Balok Pada Konstruksi Bangunan Gedung. Jurnal Ilmiah $\begin{array}{lll}\text { Poli } & \text { Rekayasa, } & \text { 15(1), }\end{array}$

54 Ardiansyah, et al. https://doi.org/10.30630/jipr.15.1.140

Alfons Willyam Sepang Tjakra, B. J., Ch Langi, J. E., \& O Walangitan, D. R. (2013). Manajemen Risiko Keselamatan Dan Kesehatan Kerja (K3) Pada Proyek Pembangunan Ruko Orlens Fashion Manado. Jurnal Sipil Statik, 1(4), 282-288.

Aloko, M. N. (2018). Risk Assessment Process for Construction Projects in Afghanistan. International Journal of Advanced Engineering Research and Science, 5(8), 211217. https://doi.org/10.22161/ijaers.5.8.26

Anwar, F. N., Farida, I., \& Ismail, A. (2016). Analisis Manajemen Risiko Kesehatan Dan Keselamatan Kerja (K3) Pada Pekerjaan Upper Structure Gedung Bertingkat (Studi Kasus Proyek Skyland City - Jatinangor). Jurnal Konstruksi, 12(1), 1-13. https://doi.org/10.33364/konstruksi/v.12-1.272

Bondroini, S., Kurniawan, F., Tistogondo, J., Engineering, C., \& Program, S. (2012). Implementation of Occupational Health and Safety Management Systems (SMK3) in Development Projects Mall and Apartments " $X$ " in Surabaya. 39-48.

Built, T., \& Review, H. E. (2011). Construction Risk Modelling and Assessment: Insights from a Literature Review. Journal of the Built and Human Environment Review, 4(1), 87-97.

Christina, W. Y., Ludfi, D., \& Thoyib, A. (2012). Pengaruh Budaya Keselamatan Dan Kesehatan Kerja ( K3 ) Terhadap Kinerja Proyek Konstruksi. Jurnal Rekayasa Sipil, 6(1), 83-95.

Devi, M. R., Ismail, A., \& Walujodjati, E. (2018). Identifikasi Faktor Risiko Kecelakaan Kerja Menuju Zero Accident pada Proyek Pembangunan Jalan Tol Cisumdawu Phase II. Jurnal Konstruksi Sekolah Tinggi Teknologi Garut, 16(2), 1-8.

Efendi, D., Hidayah, E., \& Hasanuddin, A. (2020). U KaRsT. Mapping of Landslide Susceptible Zones by Using Frequency Ratios at Bluncong, 5(1), 126-141. https://doi.org/10.1016/j.proeng.2016.11.753.A

Endroyo, B., Semarang, U. N., Yuwono, B. E., \& Trisakti, U. (2016). IMPLEMENTATION OF OCCUPATIONAL HEALTH AND SAFETY MANAGEMENT IN DEVELOPING COUNTRIES , STUDY IN CONSTRUCTION FIELD IN IMPLEMENTATION OF OCCUPATIONAL HEALTH AND SAFETY MANAGEMENT IN DEVELOPING COUNTRIES , STUDY IN CONSTRUCTION FIELD IN INDONESIA. January 2017. https://doi.org/10.21506/j.ponte.2016.12.7

Fauzania, P. N., Aryanti, T., Herman, N. D., \& Putri, A. C. (2019). The Safety Awareness of Construction Workers Regarding Workplace Health and Safety Standard. 299(Ictvet 2018), 424-426. https://doi.org/10.2991/ictvet18.2019 .96

Friyandary, B., Ihsan, T., \& Lestari, R. A. (2020). M k m i. 331344. https://doi.org/10.14710/mkmi.19.5.331-344

Goh, C. S., \& Abdul-Rahman, H. (2013). The identification and management of major risks in the Malaysian construction industry. Journal of Construction in Developing Countries, 18(1), 19-32. https://doi.org/10.9790/5933- 


\section{3}

Hidayat, I. P., \& Siswoyo. (2020). Analisa Risiko Kesehatan Dan Keselamatan Kerja Pada Proyek Pembangunan Perumahan Di Sidoarjo Jatim. Jurnal Rekayasa Dan Manajemen Konstruksi, 8(1), 35-44.

Industrial, A., Journal, E., Munang, A., Mansur, A., Studi, P., Industri, T., \& Tengah, J. (2018). Manajamen Risiko Keselamatan Dan Kesehatan Kerja ( K3 ) Proyek Pembangunan. 02(01).

Iribaram, F. W., Huda, M., Program, M., Teknik, S., Program, D., Teknik, F., Studi, P., Sipil, T., Teknik, F., Wijaya, U., Surabaya, K., Surabaya, K., Timur, J., Kerja, R. T., Pelaksanaan, R., \& Kartesius, D. (2018). Analisa resiko biaya dan waktu konstruksi pada proyek pembangunan apartemen biz square rungkut surabaya. Rekayasa Dan Manajemen Konstruks, 6(3), 141-154.

Jawat, I. W., \& Suwitanujaya, I. N. (2018). Estimasi Biaya Pencegahan Dan Pengawasan K3 Pada Proyek Konstruksi. PADURAKSA: Jurnal Teknik Sipil Universitas Warmadewa, 7(1), 88-101. https://www.ejournal.warmadewa.ac.id/index.php/padura $\mathrm{ksa} /$ article/view/820

Karim, N. A. A., Rahman, I. A., Memmon, A. H., Jamil, N., \& Azis, A. A. A. (2012). Significant risk factors in construction projects: Contractor's perception. CHUSER 2012 - 2012 IEEE Colloquium on Humanities, Science and Engineering Research, Chuser, 347-350. https://doi.org/10.1109/CHUSER.2012.6504337

Karimiazari, A., Mousavi, N., Mousavi, S. F., \& Hosseini, S. (2011). Risk assessment model selection in construction industry. Expert Systems with Applications, 38(8), 91059111. https://doi.org/10.1016/j.eswa.2010.12.110

Kasus, S., Di, A., \& Dan, J. (2017). Analisis Pengelolaan Risiko Kualitas Pada Tahap Pelaksanaan Konstruksi Gedung Tinggi (Studi Kasus : Apartemen Di Jakarta Dan Depok). Jurnal Ilmiah Desain Dan Konstruksi, 16(1), 10-20.

Kerja, K. (2019). ANALISA KAJIAN KESEHATAN DAN KESELAMATAN KERJA. 2(1), 28-39.

Komponen, P., Manajemen, S., Safira, S., Ramdhan, D. H., Sistem, K., Kesehatan, M., \& Umum, P. (2019). Proyek melalui Peraturan Menteri Sistem Manajemen Kesehatan dan.

Lestari, F., Sunindijo, R. Y., Loosemore, M., Kusminanti, Y., \& Widanarko, B. (2020). A safety climate framework for improving health and safety in the Indonesian construction industry. International Journal of Environmental Research and Public Health, 17(20), 120. https://doi.org/10.3390/ijerph17207462

Lestari, U. S. (2018). Jurnal kacapuri. 1, 102-114.

Mahendra, R., Yakin, K., \& Bustamin, M. O. (2019). Kajian Pengetahuan Dan Sikap Pekerja Terhadap Keselamatan Dan Kesehatan Kerja (Studi Kasus Pada Proyek Avian Tower Surabaya). Ge-STRAM: Jurnal Perencanaan Dan $\begin{array}{lll}\text { Rekayasa } & \text { Sipil, } & 2(2),\end{array}$ https://doi.org/10.25139/jprs.v2i2.1931

Manurung, E. H. (2020). Perencanaan K3 Pekerjaan Bidang Konstruksi **. 49-54.
Mempengaruhi, S., Kerja, K., \& Proyek, P. (2013). ISSN : 19636590 ( Print) ISSN : 2442-2630 (Online).

Nadhila, A. N., Wisnumurti, \& Devia, Y. P. (2018). Analisa Manajemen Risiko Keselamatan Dan Kesehatan Kerja (K3) Pada Pembangunan Gedung Fakultas Pertanian Universitas Brawijaya. Jurnal Mahasiswa Jurusan Teknik Sipil, $\quad$ 1(1), 284-294. http://sipil.studentjournal.ub.ac.id/index.php/jmts/article/ view/635

Nasrul. (2015). Manajemen Risiko Dalam Proyek Konstruksi Ditinjau Dari Sisi Manajemen Waktu. Jurnal Momentum, 17(1), 50-54.

Norken, I., Yudha Astana, I., \& Ayu Manuasri, L. (2012). Manajemen Risiko Pada Proyek Konstruksi Di Pemerintah Kabupaten Jembrana. Jurnal Ilmiah Teknik Sipil, 16(2), 202-211.

Nugroho, D. F., Yakin, K., B, M. O., Sipil, P. T., \& Teknik, F. (2018). Kajian Risiko Kecelakaan Kerja Terhadap Manajemen Kesehatan Dan Keselamatan Kerja ( K3 ) ( Pembangunan Villa Grand Sinensis PT. Wahana Karya Wijaya ). 01(September), 95-101.

Nurainiyah, \& Agustapraja, H. R. (2019). PENERAPAN STANDART KESELAMATAN DAN KESEHATAN KERJA (K3) PROYEK JASA KONSTRUKSI (Studi Kasus: Pembangunan Gedung Kantor Pemkab Lamongan). Jurnal CIVILLa Vol, 4(1), 214-219.

Nurhuda, D. S., Sutrisno, W., \& Galuh, D. L. C. (2019). Analisis Risiko Keterlambatan Waktu Pada Pelaksanaan Proyek Pembangunan Spbu ( Studi Kasus Di Kabupaten Bantul, Yogyakarta ). Bangun Rekaprima, 05, 19-28.

Nurlela, \& Suprapto, H. (2010). Identifikasi dan Analisis Manajemen Risiko Pada Proyek Pembangunan Infrastruktur Bangunan Gedung Bertingkat. Jurnal Ilmiah Desain Dan Konstruksi, 13(2), 114-124.

Ohsas, D. M. (n.d.). 1) , 2) , 2). 1-9.

Pasarong, M., Mara, J., \& Sopacua, H. A. I. (2021). Analisis Penerapan Keselamatan dan Kesehatan Kerja Pada Pekerjaan Struktur Di Proyek Renovasi Gedung Lembaga Penjaminan Mutu Pendidikan (LPMP) Sulawesi Selatan. Paulus Civil Engineering Journal, 3(2), 220-227. https://doi.org/10.52722/pcej.v3i2.250

Pesa, F. A., \& Hendra, T. (2017). Tinjauan Penerapan Sistem Manajemen Keselamatan dan Kesehatan Kerja ( SMK3 ). Jom FTEKNIK, 4(1), 1-11.

Priyono, A. F., \& Harianto, F. (2019). Analisis Penerapan Sistem Manajemen K3 dan Kelengkapan Fasilitas K3 Pada Proyek Kontruksi Gedung Di Surabaya. Jurnal Rekayasa Tenik Sipil Universitas Madura, 4(2), 11-16.

Rastogi, N. (2016). Risk Mitigation In Construction Contracts. International Research Journal of Engineering and Technology (IRJET), 03(02).

Renault, B. Y., \& Agumba, J. N. (2016). Risk management in the construction industry: A new literature review. MATEC Web of Conferences, 66, 6-11. https://doi.org/10.1051/matecconf/20166600008

Restuputri, D. P., Prima, R., \& Sari, D. (2015). The Analysis of 
Work Accident by Using Hazard and Operability Study (HAZOP) Method Dian Palupi RePurnama, D. S. (2015). Analisia Penerapan Metode HIRARC (Hazard Identification Risk Assessment and Risk Control) dan HAZOPS (Hazard and Operability Study) dal. 13.

Reza Hosseini, M., Chileshe, N., Jepson, J., \& Arashpour, M. (2016). Critical success factors for implementing risk management systems in developing countries. Construction Economics and Building, 16(1), 18-32. https://doi.org/10.5130/AJCEB.v1i1.4651

Rezakhani, P. (2012). Classifying Key Risk Factors in Construction Projects. The Bulletin of the Polytechnic Institute of Jassy, Construction and Architecture Section, 62(2), 27-38.

Risiko, A., Dan, K., Kerja, K., Pendekatan, M., Dan, H., Job, M., Analysis, S., Jannah, M. R., Unas, S. El, \& Hasyim, M. H. (n.d.). PADA STUDI KASUS PROYEK PEMBANGUNAN MENARA X DI JAKARTA ( Risk Analysis of Occupational and Safety Using HIRADC Approach and Job Safety Analysis Method in the Case Study of Tower Project $X$ in Jakarta ).

Rumimper, R. R., Sompie, B. F., Pascasarjana, D., Sipil, T., \& Sam, U. (2015). Perumahan Di Kabupaten Minahasa Utara. Jurnal Ilmiah Media Engineering, 5(2), 381-389.

Safira, S., \& Ramdhan, D. H. (2020). Inclusion of Construction Occupational Health and Safety Management System (OHSMS) Components in Building Construction Project. National Journal of Occupational Health and Safety, $1(1), 30-37$.

Salleh, F., Palaniappan, S., Theng, I. L. P., Helmi, H. N. M., Hamid, A. A., \& Kassim, N. M. (2020). A review on risk management implementation in the construction industry. Journal of Critical Reviews, 7(11), 562-567. https://doi.org/10.31838/jcr.07.11.102

Saraswati, Y., Ridwan, A., \& Iwan Candra, A. (2020). Analisis Penerapan Keselamatan Dan Kesehatan Kerja (K3) Pembangunan Gedung Kuliah Bersama Kampus C Unair Surabaya. Jurnal Manajemen Teknologi \& Teknik Sipil, 3(2), 247. https://doi.org/10.30737/jurmateks.v3i2.1111

Sari, N., Mulyani, E., \& M.Nuh, S. (2016). Manajemen Resiko Keselamatan Dan Kesehatan Kerja Pada Pekerjaan Konstruksi. Jurnal Mahasiswa Teknik Sipil Universitas Tanjungpura, 2(2), 1-14 http://jurnal.untan.ac.id/index.php/JMHMS/article/view/1 $6159 / 14071$

Schieg, M. (2006). Risk management in construction project management. Journal of Business Economics and Management, $7(2), \quad 77-83$. https://doi.org/10.1080/16111699.2006.9636126

Science, E. (2021). Analysis on risk management of occupational health and safety on ongoing building project Analysis on risk management of occupational health and safety on ongoing building project. https://doi.org/10.1088/1755-1315/794/1/012025

Serpell, A., Ferrada, X., \& Rubio, N. L. (2017). Fostering the effective usage of risk management in construction. Journal of Civil Engineering and Management, 23(7), 858-867.

https://doi.org/10.3846/13923730.2017.1321578
Serpella, A. F., Ferrada, X., Howard, R., \& Rubio, L. (2014). Risk Management in Construction Projects: A Knowledge-based Approach. Procedia - Social and Behavioral $\quad$ Sciences, 119, 653-662. https://doi.org/10.1016/j.sbspro.2014.03.073

Sharma, S. K., \& Swain, N. (2011). Risk Management in Construction Projects. Asia Pacific Business Review, $7(3)$, 107-120. https://doi.org/10.1177/097324701100700310

Sigit, A., \& Azizah, A. N. (2019). Analysis Implementation of Occupational Health and Safety Management System in Building Construction Project at " 7 in 1 " Project, Yogyakarta State University. 1013.

Situmorang, B. E., Arsjad, T. T., Tjakra, J., Sipil, T., Sam, U., Manado, R., Manado, J. K. B., \& Ratulangi, S. (2018). Analisis Risiko Pelaksanaan Pembangunan Proyek Konstruksi Bangunan Gedung. Tekno, 16(69), 31-36.

Sivagami, M. M., \& Sarath, M. (2008). Risk Management in Construction: a Literature Review. International Research Journal of Engineering and Technology, 510, 510-514.

Soputan, G., Sompie, B., \& Mandagi, R. (2014). Manajemen Risiko Kesehatan Dan Keselamatan Kerja (K3) (Study Kasus Pada Pembangunan Gedung Sma Eben Haezar). Jurnal Ilmiah Media Engineering, 4(4), 99095.

Sucita, I. K., \& Broto, A. B. (2011). Identifikasi dan Penanganan Risiko K3 pada Proyek Konstruksi Gedung. Poli Teknologi, 10(1), 83-92.

Suparno, M. (2015). Manajemen Risiko Dalam Proyek Konstruksi. Bangunan, 20(1).

Susilowati, I. H., Kurniawidjaja, L. M., Tejamaya, M., Pratomo, S., Hasiholan, B. P., Putri, A. A., \& Sitanggang, A. N. (2021). Rapid Assessment on Occupational Health and Safety Issues Faced by Young Workers in Indonesia Construction Sectors. In Lecture Notes in Networks and Systems: Vol. 222 LNNS. Springer International Publishing. https://doi.org/10.1007/978-3-030-746117_28

Sutawijaya, A. H., Nawangsari, L. C., Buana, U. M., \& Management, M. (2017). THE STRATEGIC OF IMPLEMENTATION HEALTH AND SAFETY TO.

Szymański, P. (2017). Risk management in construction projects. Procedia Engineering, 208(January 2017), 174182. https://doi.org/10.1016/j.proeng.2017.11.036

Tadayon, M., Jaafar, M., \& Nasri, E. (2012). An Assessment of risk identification in large construction projects in Iran. Journal of Construction in Developing Countries, 17(SUPPL. 1), 57-69.

Taufik, M., Muttaqin, M., \& Rauzana, A. (2018). Faktor-Faktor Risiko Waktu Yang Mempengaruhi Biaya Pelaksanaan Proyek Konstruksi Gedung Di Provinsi Aceh. Jurnal Arsip Rekayasa Sipil Dan Perencanaan, 1(4), 156-163. https://doi.org/10.24815/jarsp.v1i4.12466

Teknik, F., Teknik, J., Putra, U., \& Yptk, I. (2021). http://jurnal.umsb.ac.id/index.php/RANGTEKNIKJOURN AL. 4(1). 
Tesfaye, E., Berhan, E., \& Kitaw, D. (2016). A Comprehensive Literature Review on Construction Project Risk Analysis. International Journal of Risk and Contingency Management, 5(4), 1-15. https://doi.org/10.4018/ijrcm.2016100101

Tjakra, J., \& Sangari, F. (2011). Analisis Resiko Pada Proyek Konstruksi Perumahan Di Kota Manado. Jurnal Ilmiah Media Engineering, 1(1), 29-37.

Violante, A. (2018). Risk Management in Construction Projects: Are Small Companies Prepared? MOJ Civil Engineering, 4(1), 1-7. https://doi.org/10.15406/mojce.2018.04.00090

Walter Saunders Pacheco do Vale, J., \& Monteiro de Carvalho, M. (2017). Risk and Uncertainty in Projects Management: Literature Review and Conceptual Framework. Revista Gestão Da Produção Operações e Sistemas, 12(2), 93-120. https://doi.org/10.15675/gepros.v12i2.1637

Widianto, T., \& Huda, M. (2019). Analisa Risiko Proyek Pembangunan Universitas Ciputra. 7(1), 17-24.

Winda PurnamaTagueha, Jantje B Mangare, \& Tisano Tj. Arsjad. (2018). Manajemen Resiko Keselamatan dan kesehatan Kerja (K3) Pada Proyek Kontruksi (Studi Kasus: Pembangunan Gedung Laboratorium Fakultas Teknik Unsrat). Sipil Statik, 6(11), 907-916.

Yuliani, U. (2017). Manajemen Risiko Keselamatan dan Kesehatan Kerja (K3) Pada Infrastruktur Gedung Bertingkat. Jurnal Desain Konstruksi, 16(1), 92-100. 
